\title{
The Transformation of the Higher Education System in Turkey after 2002: A Game Theoretic Analysis
}

\author{
Zekeriya Tuzen ${ }^{1}$, Caglar Yurtseven ${ }^{2}$ \\ ${ }^{1}$ Department of Political Science and International Relations, Bahcesehir University, Istanbul, Turkey \\ ${ }^{2}$ Department of Economics, Bahcesehir University, Istanbul, Turkey \\ Email: zekeriyatuzen@yahoo.com, cayurtseven@yahoo.com
}

Accepted 13 February 2016; published 16 February 2016

Copyright (C) 2016 by authors and Scientific Research Publishing Inc.

This work is licensed under the Creative Commons Attribution International License (CC BY). http://creativecommons.org/licenses/by/4.0/

c) (i) Open Access

\begin{abstract}
The higher education system in Turkey suffered from capacity problem during the 1980s and the 1990s. After the election in 2002, to solve the problem, the Justice and Development Party governments have invested in higher education through opening new universities, increasing the total capacity in higher education, and sending more students abroad especially for graduate studies. In this paper, noting the conservative structure of the Justice and Development Party, we determine whether a dilemma exists between these liberal practices and the party's conservatism. By constructing a one-period sequential game, we show that heavy investment in higher education by the Justice and Development Party is not contradictory and, in fact, inevitable, as long as it tries to maximize its vote in the short-medium run.
\end{abstract}

\section{Keywords}

Higher Education, AK Parti, One-Period Game, Conservatism, Study Abroad

\section{Introduction}

One of the most interesting problems of the Turkish higher education system in the 1980s and the 1990s was the limited capacity of universities to absorb candidates. This extensive problem arose from the fact that the number of students competing for enrolment outnumbered the total capacity of university programs each consecutive year. Prior to the general election in 2002, all parties promised to invest in higher education through increasing the number of universities and the number of students enrolled in programs [1] [2].

Since 2002, the Justice and Development Party (Formal Turkish abbreviation: AK Parti, Turkish initials: AKP) 
governments have tried to solve this problem by opening new universities and creating new capacity in the existing ones. The number of available seats in universities for the incoming class in 2002 was 662,336 and in 2013 it was about 1 million. The number of universities rose from 76 in 2002, to 175 in 2013 [3]. At the same time, Turkey has strengthened its ties mainly with western universities with the help of continuing investment in programs such as the Socrates-Erasmus and Ministry of Education's fellowships designed for undergraduate and graduate students to study abroad ${ }^{1}$. The total number of state-sponsored outgoing students has increased from 500 in 2002 to 17,500 in 2013 [4] [5]. The higher education policy of the AKP governments increased the number of universities and the number of students enrolled which has made getting a university education much easier than it used to be. In this paper, we focus on the main aspects of this "liberal" transformation under a "conservative" party: AKP.

Investment in Turkish higher education has come along with externalities. For example, millions of young women and men have mobilized and started to independently live apart from their parents instead of leaving their parents' houses only at the time of marriage. Apart from university students, $90 \%$ of single people live with their families in Turkey [6]. Thousands of university students have utilized exchange programs and encountered western life styles living in the European Union (EU) countries and the United States of America (USA). In addition, research shows that higher educated people are more likely to vote for liberal-modernist parties. (For details, see Part 3). Considering these externalities, "conservatives" may be expected to invest in higher education in a "conservative manner”. The AKP is a conservative party in the Turkish political context, as declared by its leaders and its program [1]. However, the huge increase in the number of universities, university students, and outgoing exchange students to western countries during the AKP term seems to contradict the expectation stated above.

The aim of this article is to examine whether a dilemma exists in the case of AKP investment in higher education in Turkey, taking into consideration the reality that the AKP garners relatively low voting support from higher educated people. By constructing a one-period game, we actually show that it is not unexpected for a conservative party to heavily invest in liberal higher education in Turkey, as long as it tries to maximize its votes in the short or medium run.

In the paper, first, we evaluate the conservatism of the AKP and then we examine its actions concerning higher education. After setting up the model, we discuss the results with reference to party programs. Finally, we briefly conclude.

\section{Conservatism and the AKP}

Even for a simple statement about the dilemma of the liberal transformation of the higher education system by the AKP, we have to understand if the AKP is really a conservative party.

Studies on Turkish politics have defined center-right political parties as the representatives of "political conservatism" [7]-[10]. The core values of centre-right party identities in Turkey that constitute the essence of conservatism are traditionalism, religiosity, localism and nationalism [7]. Moreover, conservatism among these political parties is commonly a result of pragmatism. In this regard, pragmatic reasons led the AKP leadership to label itself as a conservative democrat party which recognizes the cultural and religious notions of Turkish credentials [11].

The religious discourse of the party founders, particularly its leaders, is accepted as one of the most important indicators of its conservative policies [12]. In retrospect, the AKP has a strong tradition of religious discourse stemming from the National Vision ${ }^{2}$ movement that dates back to the 1970s. It emerged from the last generation of the movement at the beginning of the new millennium as the "innovationists" wing separated from the "traditionalist” wing of the Virtue Party (FP). After its foundation on August 14, 2001, the party leaders introduced themselves as "conservative democrats," which is a new concept in Turkish politics, and embraced the party program as the promoter of "conservative democracy.” It is clearly detailed in the book by Yalcin Akdogan, advisor to the party leader, that the party gives priority to the protection of the cultural accumulation of the society and family because they are "cultural conservatives” [13]. Hence, we can conclude from the relevant literature and its own

\footnotetext{
${ }^{1}$ Socrates-Erasmus is the student exchange program authorized by the EU and it covers undergraduate and graduate students in European countries. Students do not pay tuition fee to the receiving university during their study for 1 - 2 semesters.

${ }^{2}$ The National Vision (MilliGörüş) is a political movement started in 1970s. The movement established the National Order Party (MNP), the National Salvation Party (MSP), the Welfare Party (RP), the Virtue Party (FP) and the Felicity Party (SP). All these Parties, except the SP, were consecutively banned from the political life by the Turkish Constitutional Court due to the allegations of having violated the principles of secular state system. The AKP separated from the FP after its banning and kept a clear distance between the SP and its party discourse [8].
} 
statements that the AKP is a conservative political party. The AKP won the parliamentary elections on November 3, 2002 and has run the country for nearly 13 years with a majority of seats in the Turkish Parliament.

\section{Higher Education and Conservatism}

The AKP has invested in higher education and has increased the number of students through opening new universities. However, these investments have the potential of causing contradictory consequences for the conservative AKP.

First, higher educated people with higher emphasis on secular-rational values mainly vote for the liberalmodernist parties, whereas lower educated people with higher emphasis on traditional values mainly vote for the AKP [14]. It is obvious that with the investments in higher education, the general education level of the country has increased.

The polls on conservatism in Turkey also show that higher educated people, when compared to lower educated people, are less likely to vote for the conservative AKP. For the relationship between education and voting behaviour, see the results of the polls after the March 30, 2014 local, and the June 7, 2015 parliamentary elections by the well-known Turkish research company, KONDA [15] [16], below.

The above Table 1 and Table 2 show that 9\% - 10\% of AKP voters have at least a university degree, whereas $22 \%$ of CHP voters have at least a university degree. The AKP's share of voters who have at least a university degree is less than the Turkish average which is $14 \%$.

In addition, when we correlate the education level (\% of at least high school graduates) of cities in Turkey with their vote rates we observe a negative correlation between vote rates for the AKP and education level of the cities. On the contrary, there is an even more significant positive correlation between vote rates of the Republican People's Party (Formal Turkish abbreviation: CHP, Turkish initials: CHP) and education level. CHP's at least university degree voter share is the highest although the AKP is putting forth great effort to increase the education level of the country (Table 3).

Table 1. Education level by parties in March 30, 2014 local elections ${ }^{3}$.

\begin{tabular}{cccc}
\hline & Pre-high school & High school & At least university \\
\hline Turkey & 58 & 28 & 14 \\
AKP voters & 67 & 23 & 10 \\
CHP voters & 43 & 35 & 22 \\
MHP voters & 49 & 33 & 18 \\
HDP voters & 71 & 24 & 5 \\
\hline
\end{tabular}

Source: KONDA Research and Consultancy Company.

Table 2. Education level by parties in the June 7, 2015 parliamentary elections.

\begin{tabular}{cccc}
\hline & Pre-high school & High school & At least university \\
\hline Turkey & 58 & 28 & 14 \\
AKP voters & 68 & 23 & 9 \\
CHP voters & 46 & 32 & 22 \\
MHP voters & 48 & 35 & 17 \\
HDP voters & 64 & 24 & 12 \\
\hline
\end{tabular}

Source: KONDA Research and Consultancy Company.

Table 3. Correlation between cities general education levels and party votes.

\begin{tabular}{lccccc}
\hline & AKP & CHP & HDP & MHP & \\
\hline Education & -0.0259 & 0.6173 & -0.3838 & 0.2079 & All cities, all elections (2002, 2004, 2007, 2009, 2011) \\
Education & -0.2001 & 0.7247 & -0.4084 & 0.1919 & Parliamentary elections (2002, 2007, 2011), greater cities ${ }^{4}$ \\
\hline
\end{tabular}

Source: Authors' own calculations based on raw data from the Turkish Supreme Election Board and Turk Stat [19] [20].

${ }^{3}$ The Peoples’ Democratic Party (Formal Turkish Abbreviation: HDP, Turkish Initials: HDP, (Kurdish Nationalist Party)). The Nationalist Movement Party (Formal Turkish Abbreviation: MHP, Turkish Initials: MHP, (Turkish Nationalist Party)).

${ }^{4}$ The Formal List of the Greater Cities of Turkey Valid before 2012: Adana, Ankara, Antalya, Bursa, Diyarbakır, Erzurum, Eskişehir, Gaziantep, İstanbul, İzmir, Kayseri, Kocaeli, Konya, Mersin, Sakarya, Samsun. 
Second, liberal higher education promotes outward-oriented approaches, which increase international student mobility flows. The Socrates-Erasmus and other exchange programs are the main examples of this. Outwardoriented approaches pave the way for intercultural dialogue that helps to erode relatively close and conservative notions which are mainly dominant in the rural parts of Turkey [17]. When students from rural areas begin to participate in the Socrates-Erasmus or other exchange programs, they encounter foreign cultures and life styles that may affect their close conservative notions [18].

As an example, we gathered important information about the education level of the participants of the Gezi events in the summer of 2013 which started with environmental concerns but turned into mass protests of the AKP policies [21]. We see that three fifths of the activists who disagree with the policies of the AKP have at least a university degree. This ratio is striking when we remember the fact that only $14 \%$ of the whole Turkish population are university graduates [22]. For detailed information, see the Table 4 below.

\section{AKP Investments in Higher Education}

After considering the possible effects of opening new universities and promoting a liberal, outward looking higher education on the conservative AKP, we provide some information about its actions on these areas.

First, the number of universities increased from 76 in 2002 to 175 in 2013 [23]. This gave way to a big increase in the number of university students in Turkey, which has grown from 1.8 million in 2002 to 5 million in 2013 [24]. (For the change in the number of students in Turkey, see Figure 1).

This progress has actually been a response to the big demand for university education in Turkey. In Figure 2 and Figure 3, we provide information about the change in the number of applications, capacities, and the total acceptance ratio of universities in Turkey [25]. The increase in the acceptance ratio has actually come as a relief for Turkish youth in the sense that it is now easier to get into the university programs in Turkey.

In the previous section we discussed the possible effects of exchange programs on the conservative AKP. Below, in Table 5, the change in the numbers of participants in Socrates-Erasmus program [26] and, in Table 6, the change in the numbers of students who utilize government scholarships for graduate studies abroad are given [27]. Both tables show a big increase in the number of students who go abroad (Country information for the Socrates-Erasmus program is given in Table 7 [28]) for higher education. The Socrates-Erasmus program itself is a developing program so it is not surprising to see an increasing trend in participation. However, being a non-EU member, the increase of participants from Turkey is still important. Taking all this into consideration, it

Table 4. Education level of the participants in the Gezi events.

\begin{tabular}{cccc}
\hline & Pre-high school & High school & At least university \\
\hline Turkey & 58 & 28 & 14 \\
Gezi participants & 8 & 35 & 57 \\
\hline
\end{tabular}

Source: KONDA Research and Consultancy Company.

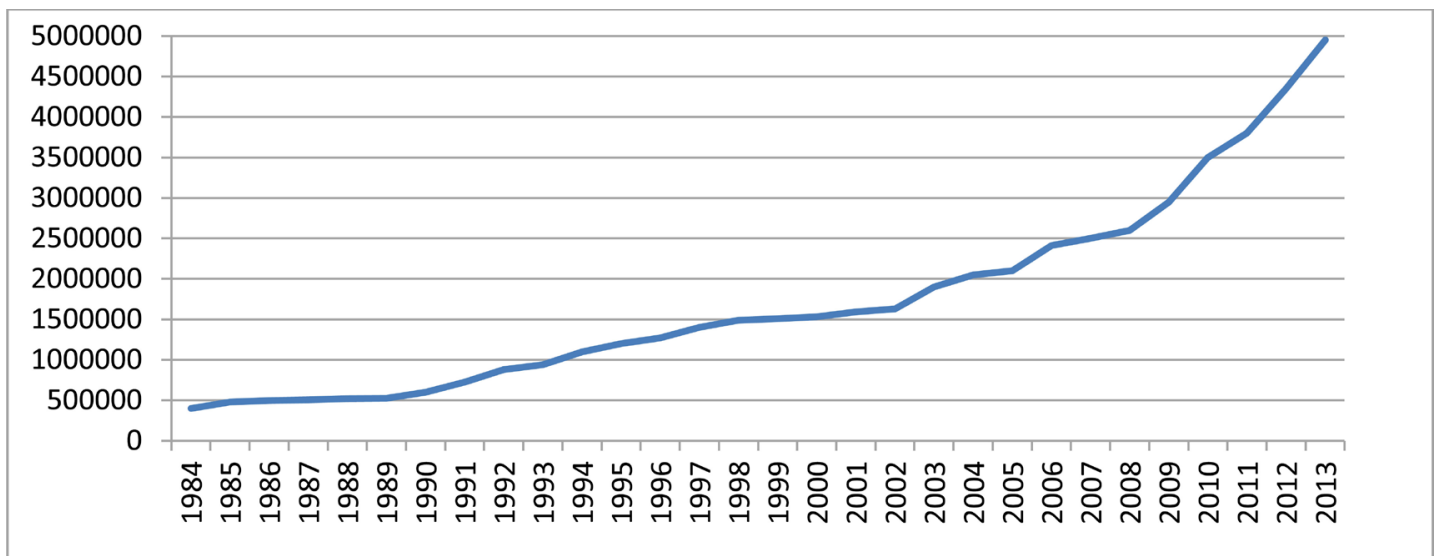

Source: Gunay, D. and Gunay, A. (2011) and Student Selection and Placement Center (ÖSYM).

Figure 1. Total number of university students in Turkey. 


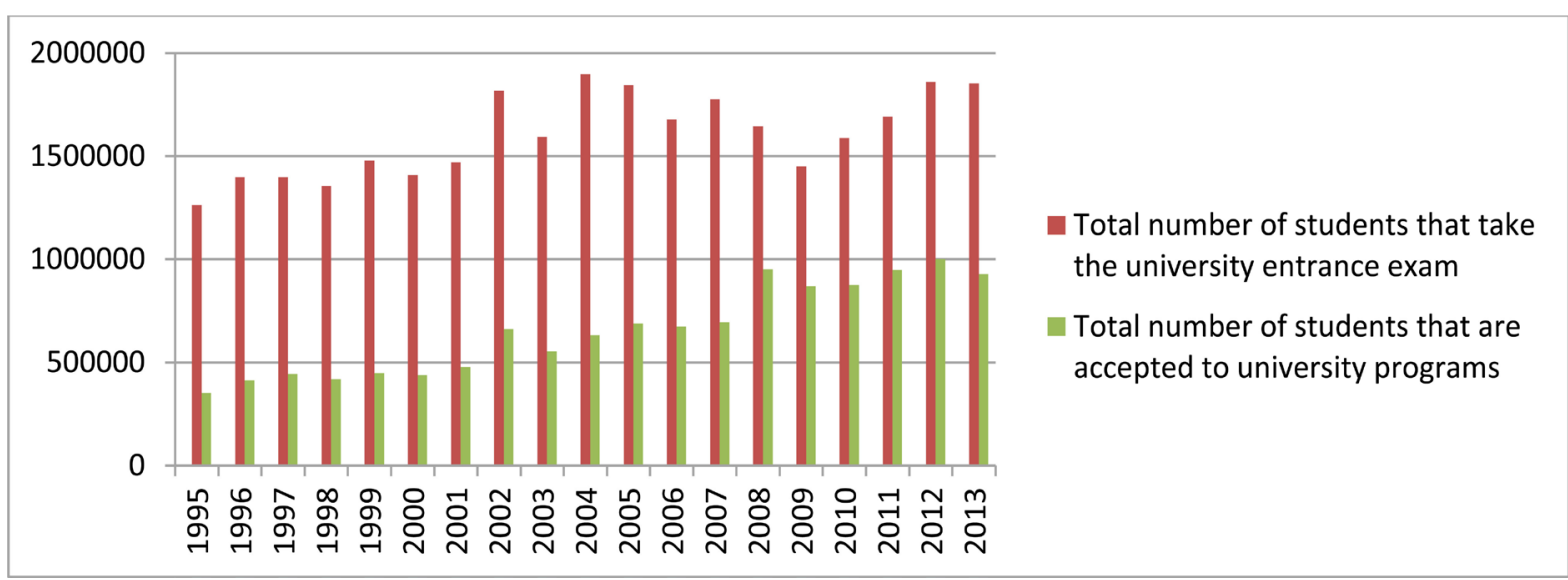

Source: Student Selection and Placement Center (ÖSYM).

Figure 2. Basic statistics about university entrance examinations in Turkey I.

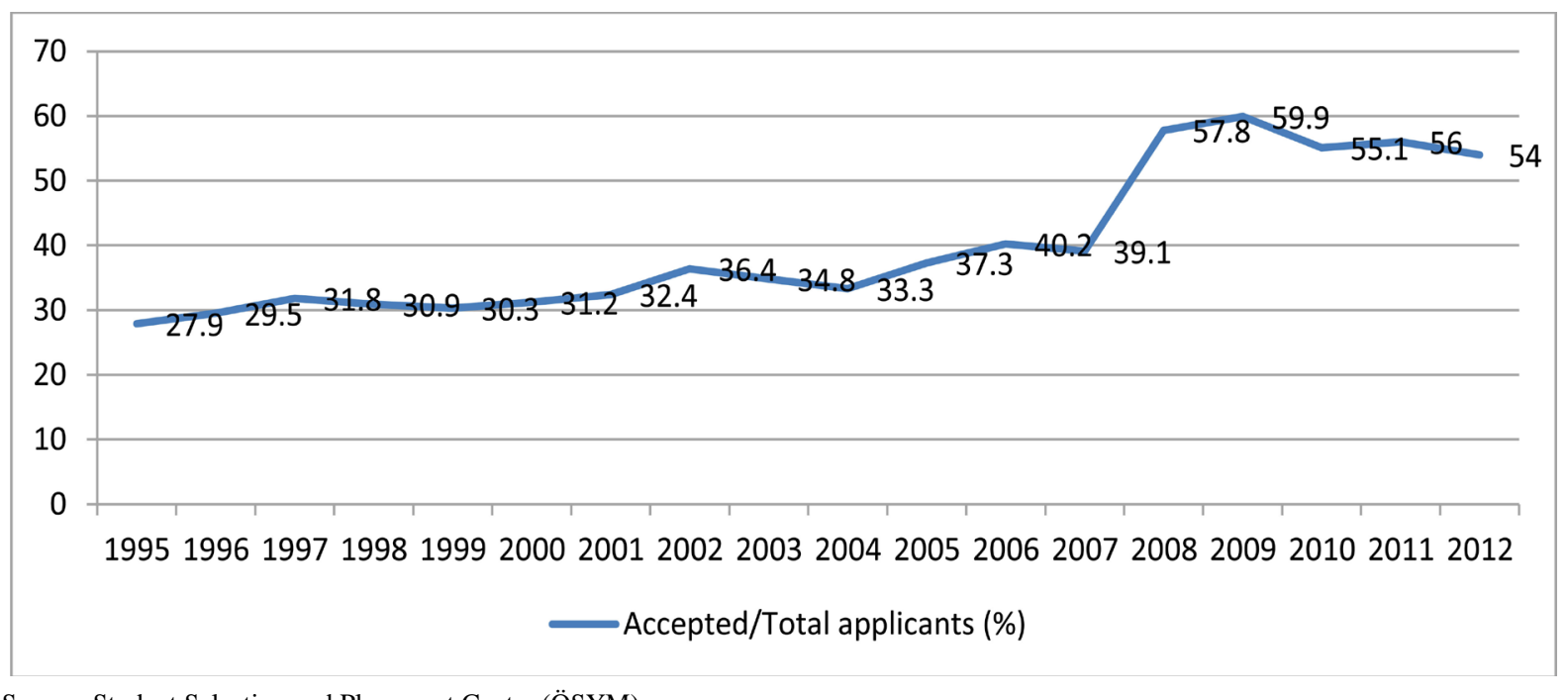

Source: Student Selection and Placement Center (ÖSYM).

Figure 3. Basic statistics about university entrance examinations in Turkey II.

Table 5. Erasmus exchange statistics for Turkey I.

\begin{tabular}{lccc}
\hline & Total outgoing & Incoming undergraduate students & Outgoing undergraduate students \\
\hline $2003-2004$ & 1980 & 17 & 128 \\
$2004-2005$ & 5210 & 299 & 1142 \\
$2005-2006$ & 11,304 & 828 & 2852 \\
$2006-2007$ & 16,997 & 1321 & 4438 \\
$2007-2008$ & 23,521 & 1982 & 7119 \\
$2008-2009$ & 27,119 & 2658 & 7794 \\
$2009-2010$ & 32,309 & 3336 & 8758 \\
$2010-2011$ & 38,945 & 4320 & 10,065 \\
$2011-2012$ & 44,995 & 4700 & 11,664 \\
$2012-2013$ & 60,483 & 5100 & 13,591 \\
$2013-2014$ & 66,481 & 5425 & 14,985 \\
\hline
\end{tabular}

Source: Turkish National Agency. 
Table 6. Students who go abroad by Turkish ministry of national education’s fellowships.

\begin{tabular}{ccccccc}
\hline \multirow{2}{*}{2014} & Master & 898 & Man & 1784 & Natural sciences & 1650 \\
& Ph.D. & 1263 & Woman & 1007 & Social sciences & 1141 \\
\hline \multirow{2}{*}{2013} & Master & 1049 & Man & 1689 & Natural sciences & 1640 \\
& Ph.D. & 1194 & Woman & 981 & Social sciences & 1039 \\
\hline \multirow{2}{*}{2012} & Master & 1023 & Man & 1584 & Natural sciences & 1488 \\
& Ph.D. & 974 & Woman & 868 & Social sciences & 1034 \\
\hline \multirow{2}{*}{2011} & Master & 1032 & Man & 1383 & Natural sciences & 1299 \\
& Ph.D. & 689 & Woman & 741 & Social sciences & 825 \\
\hline \multirow{2}{*}{2010} & Master & 902 & Man & 1163 & Natural sciences & 1103 \\
& Ph.D. & 499 & Woman & 608 & Social sciences & 668 \\
\hline \multirow{2}{*}{2009} & Master & 628 & Man & 924 & Natural sciences & 843 \\
& Ph.D. & 279 & Woman & 479 & Social sciences & 560 \\
\hline \multirow{2}{*}{2008} & Master & 329 & Man & 613 & Natural sciences & 574 \\
& Ph.D. & 183 & Woman & 277 & Social sciences & 316 \\
\hline
\end{tabular}

Source: Turkish Ministry of National Education.

Table 7. Erasmus exchange statistics for Turkey II.

\begin{tabular}{cccc}
\hline Share of outgoing students' countries & $\%$ & Share of incoming students' countries \\
\hline Germany & 20 & Germany & Poland \\
Poland & 12 & Netherlands \\
Italy & 9 & France \\
Spain & 7 & Italy \\
Netherlands & 7 & Lithuania \\
France & 6 & 5 \\
\hline
\end{tabular}

Source: Turkish National Agency.

is clear that more and more students from Turkish universities have started to live abroad (mainly in western countries) for at least part of their university studies.

In conclusion, even though negative effects on the conservative structure of the youth are possible, the AKP has heavily invested in higher education by increasing the number of universities, students enrolled in higher education, and strengthening connections with western countries.

\section{The Model}

In spite of the possible negative effects on conservatism, we claim that due to the high demand for university seats and the existence of a liberal-modernist opposition party, it is totally normal for the AKP to heavily invest in higher education in the manner discussed above ${ }^{5}$.

Claim: When there is a big enough stock of high school graduates and a liberal opposition party, a vote maximizing governing party chooses to invest in a liberal higher education system, even if it is conservative.

To test the validity of this claim, we design a one-period (one election term) game in which the governing party (AKP) acts first and the opposition party (CHP) acts accordingly. The governing party, when there is already a capacity problem in universities and exchange programs due to high demand, has two options to choose from. The first one is to invest in higher education by opening new universities and sending more students abroad. The second option is not to invest in liberal higher education based on the possible results that may con${ }^{5}$ The ideological structures of the new universities, or the possible ideological transformation in the existing ones, are beyond the scope of this paper. 
tradict conservatism. The main opposition party has two options to choose from. The first one is to invest in higher education for increasing capacities and the second one is to invest in higher education to increase its quality (freedom, more liberal practices etc.). Not investing is not an option for the opposition party due to its longstanding programs, its political stance and the expectations of its voters [29].

That is, we can write the formal representation of the game as:

1) A sequential game in which the government moves first and then the opposition responds.

2) Players: $i=1,2$.

3) The set of strategies for first player $S_{1}=$ (invest, not invest).

4) The set of strategies for second player $S_{2}=$ (invest, quality) .

5) $s=\left(s_{1}, s_{2}\right)$ is the strategy profile of the game.

6) A function $\pi_{i}: S \rightarrow R$ for player $i=1$, 2 where $S$ is the set of strategy profiles, so $\pi_{i}(s)$ is player $i$ 's payoff when strategy $s$ profile is chosen.

\section{Solution:}

To solve the constructed game, we draw the following game tree in which the governing party (AKP, player 1) plays first and the opposition party's (CHP, player 2) act follows.

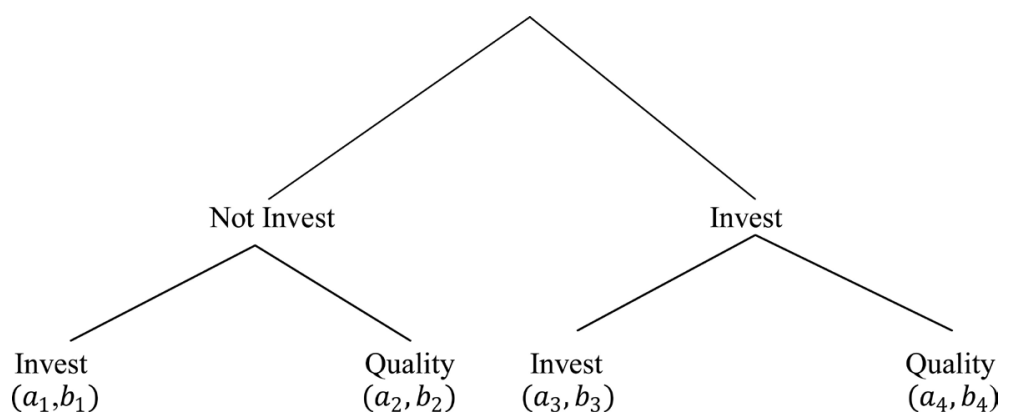

When we compare $b_{1}$ and $b_{2}$ (the payoffs of the opposition party when the current government does not invest in higher education), $b_{1}$ will be greater than $b_{2}\left(b_{1}>b_{2}\right)$. That is, if the youth's university entrance problem has yet to be solved, the opposition party will tell the voters before the next election that it will solve the problem by investing in education rather than emphasizing quality increases. According to this scenario, $\left(a_{1}, b_{1}\right)$ will be the outcome of the game if the government does not invest by opening new universities in the first period.

If the government invests by opening new universities and sending more people abroad, then $b_{3}$ and $b_{4}$ will be the possible payoffs of the opposition party. In this scenario, we expect the opposition party's propaganda to be based on increasing the quality of the education system by modernizing it because telling the voters that it will open new universities, while the current government is already known to be opening new universities, will not be as profitable for the opposition party. Hence $b_{4}$ will be greater than $b_{3}\left(b_{4}>b_{3}\right)$. That is, $\left(a_{4}, b_{4}\right)$ will be the outcome of the game if the government decides to invest in the first period.

Therefore, the current government, trying to maximize its votes in the coming election, will compare the possibilities $\left(a_{1}, b_{1}\right)$ with $\left(a_{4}, b_{4}\right)$ and act accordingly. When we remember the relatively conservative structure of Turkey, promises to increase quality and modernization, when there are already many universities, will hurt the current government less than the promise of opening new universities, when there are only a few universities. That is, $a_{4}$ will be greater than $a_{1}\left(a_{4}>a_{1}\right)$. Therefore, the maximum vote rate the government will reach in the coming election will be $a_{4}$, given the responses of the opposition ${ }^{6} .\left(a_{4}, b_{4}\right)$ is the equilibrium of the game. The government will choose to invest in education by opening new universities and connecting them better to the world. Hence, investment into the liberal higher education system in Turkey by a conservative party is not contradictory and is, in fact, inevitable, as long as it tries to maximize its vote in the short-medium run.

\section{Discussion}

When we examine the recent party programs of the governing AKP and the main opposition CHP [30], we see

${ }^{6}$ We should also remember at this point that opening universities has positive externalities in the sense that they add to a city's economy primarily through effects on the service sector. Therefore, for a developing country like Turkey, economic motivations also play a role for a policy maker in deciding to open a new university in a city. With these economic motivations, payoff for an investor party in higher education will be even larger. 
issues such as cheaper education, more accessible education, and an increase in the education budget as common promises. To understand the difference better, we focus on the details.

If we examine the party program of the Justice and Development Party, we clearly observe the emphasis on loans for higher education that can help relatively poorer students enrol in university. We interpret this as a promise for higher education for more people, that is, higher education for the relatively poorer Turkish majority. In addition, the promise of the support for foundation universities again encourages the opening of new universities around the country and focuses on the quantity of educational opportunities. To give some examples:

"Students shall benefit from educational services in accordance with their experience and skills. In this sense, students whose financial status does not allow them shall also be able to receive a high quality education."

"A loan system shall be adopted for students attending public universities, whereby they can pay for their tuition and fees and maintain a decent life. The principles and basis of the assistance for the poor students shall be established."

"Foundation universities shall be supported. The principles of the financial assistance provided to these universities from the national budget shall be re-established."

The details in the Republican People's Party's program that do not exist in the Justice and Development Party's program focus on modern values and the adaptation of the Turkish university education to the EU's university system through the Bologna process and promoting western values. The CHP does not talk about the opening of new universities but about increasing the quality of the current system through modernization. Statements focusing on the quality of the education that can be found only in the CHP's program are as follows:

"Human centred education: The universities in Turkey shall be independent, not apart from Turkish realities, democracy and should follow universal values."

"Turkish universities should help people to live in harmony with the natural environment and develop aesthetic sensibility."

"Higher education shall be configured with the Bologna process in the EU. OECD autonomy criteria shall be strongly taken into consideration."

With a careful reading of the party programs, we can conclude that the AKP focuses on quantity by supporting the education of more people through aid to the poor and the establishment of foundation universities. On the contrary, the CHP mainly emphasizes quality by supporting a university education that is more independent, modern and close to western values.

Hence, the party programs are in line with the expectations of the constructed game above in the sense that the AKP emphasizes the quantity aspect of higher education while the CHP emphasizes increases in quality or the modernization of the current system. These observations from the recent party programs actually show that both the governing and main opposition party act strategically to maximize their votes.

\section{Conclusions}

This study examines whether the AKP has followed a policy in higher education compatible with its conservative vision. Conservatism in Turkey, in general, aims to protect family and society through emphasizing traditional and religious aspects of Turkish culture. The increase in the quantity of educational opportunities, namely, opening of public and foundation universities in every city, the numbers of students accessing programs in these universities, and the number of students participating in the Socrates-Erasmus programs across EU countries and programs in the USA, seems to be liberal in nature. Thus, it can be questioned whether the AKP's approach to higher education policy is pragmatic.

We showed using game theory analysis that, as long as there is a demand for more capacity in higher education and its connections to the rest of the world, there is no dilemma for a conservative vote maximizing party to heavily invest in higher education in a liberal sense.

However, it is still true that the transformation of higher education in a liberal manner could make Turkish conservatism more vulnerable, especially in the long run. Therefore, an empirical study that provides insight about the voting behaviour of the new graduates and projections about these investments' long term effect on the conservative structure is of interest for future research.

\section{References}

[1] Justice and Development Party Program (2002) Ankara, Turkey. www.akparti.org.tr 
[2] Republican People’s Party Program (2002) Ankara, Turkey. www.chp.org.tr

[3] Student Selection and Placement Center (ÖSYM) (2002-2013) Yearly Statistics. http://www.osym.gov.tr/belge/1-7943/turkiyedeki-universiteler-ve-yuksek-teknoloji-enstitule-.html http://www.osym.gov.tr/belge/1-128/sureli-yayinlar.html

[4] Turkish National Agency (2002-2013) Yearly Reports. http://www.ua.gov.tr/basin-odasi/yay\%C4\%B1nlar

[5] Turkish Ministry of National Education (2007-2014) Yearly Reports. http://www.resmiistatistik.gov.tr/?q=tr/content/milli-e\%C4\%9Fitim-bakanl\%C4\%B1\%C4\%9F\%C4\%B1

[6] Kaya, H. and Yurtseven, C. (2016) Can Marriage Be Bad for Health? Economics and Scoiology, 9, Forthcoming.

[7] Kalaycioglu, E. (2007) Politics of Conservatism in Turkey. Turkish Studies, 8, 233-252.

[8] Özbudun, E. (2006) From Political Islam to Conservative Democracy: The Case of the Justice and Development Party in Turkey. South European Society and Politics, 11, 543-557.

[9] Cizre, U. (2002) From Ruler to Pariah: The Life and Times of the True Path Party. Turkish Studies, 3, 82-101.

[10] Taskin, Y. (2013) Hegemonizing Conservative Democracy and the Problems of Democratization in Turkey: Conservatism without Democrats? Turkish Studies, 14, 292-310.

[11] Yavuz, M.H. (2009) Secularism and Muslim Democracy in Turkey. Cambridge University Press, New York.

[12] Dagi, I. (2006) The Justice and Development Party: Identity, Politics, and Discourse of Human Rights in the Search for Security and Legitimacy. In: Yavuz, H., Ed., The Emergence of a New Turkey: Democracy and the AK Parti, Utah University Press, Salt Lake City.

[13] Akdogan, Y. (2004) Ak Partive Muhafazakar Demokrasi, Alfa Yayinlari, Ankara.

[14] Esmer, Y. (2012) Türkiye Değerler Atlası (Available in Turkish), Bahcesehir University Publications, Istanbul. http://content.bahcesehir.edu.tr/public/files/files/ATLAS\%20SUNUM\%202_10_2012\%20(2).pdf

[15] Konda (2014) 30 Mart Yerel Seçimler Sonrası Sandıkve Seçmen Analizi (Available in Turkish). Konda, Istanbul.

[16] Konda (2015) 7 Haziran Sandıkve Seçmen Analizi (Available in Turkish). Konda, Istanbul.

[17] Yilmaz, H. (2008) Conservatism in Turkey. Turkish Policy Quarterly, 7, 57-63.

[18] Demirkol, A.Y. (2013) The Role of Educational Mobility Programs in Cultural Integration: A Study on the Attitudes of Erasmus Students in Turkey toward the Accession of Turkey to European Union. Anthropologist, 16, 653-661.

[19] Turkish Supreme Election Board. https://sonuc.ysk.gov.tr/module/GirisEkrani.jsf

[20] TurkStat. http://www.tuik.gov.tr/PreIstatistikTablo.do?istab_id=1606

[21] Farro, A.L. and Demirhisar, D.G. (2014) The Gezi Park Movement: A Turkish Experience of the Twenty-First-Century Collective Movements. International Review of Sociology, 24, 176-189. http://dx.doi.org/10.1080/03906701.2014.894338

[22] Konda (2014) Gezi Raporu (Available in Turkish). Konda, Istanbul.

[23] Student Selection and Placement Centre (ÖSYM), (2002-2013) Yearly Statistics. http://www.osym.gov.tr/belge/1-7943/turkiyedeki-universiteler-ve-yuksek-teknoloji-enstitule-.html

[24] Gunay, D. and Gunay, A. (2011) 1933’den Günümüze Türk Yükseköğretiminde Niceliksel Gelişmeler (Available in Turkish). Journal of Higher Education and Science, 1, 1-22. http://dx.doi.org/10.5961/jhes.2011.001

[25] Student Selection and Placement Centre (ÖSYM), (2002-2013) Yearly Statistics. http://www.osym.gov.tr/belge/1-128/sureli-yayinlar.html

[26] Turkish National Agency (2002-2013) Yearly Reports. http://www.ua.gov.tr/basin-odasi/yay\%C4\%B1nlar

[27] Turkish Ministry of National Education (2007-2014) Yearly Reports. http://www.resmiistatistik.gov.tr/?q=tr/content/milli-e\%C4\%9Fitim-bakanl\%C4\%B1\%C4\%9F\%C4\%B1

[28] Turkish National Agency (2002-2013) Yearly Reports. http://www.ua.gov.tr/basin-odasi/yay\%C4\%B1nlar

[29] Republican People’s Party Programs (1999, 2002, 2007, 2011) Ankara, Turkey. www.chp.org.tr

[30] Justice and Development Party Program (2011) Ankara, Turkey. www.akparti.org.tr 